\title{
Collective punishment depends on collective responsibility and political organization of the target group ${ }^{\text {th }}$
}

\author{
Andrea Pereira ${ }^{\mathrm{a}, \mathrm{b}, *}$, Jacques Berent ${ }^{\mathrm{a}}$, Juan Manuel Falomir-Pichastor ${ }^{\mathrm{a}}$, Christian Staerklé ${ }^{\mathrm{c}}$, Fabrizio Butera ${ }^{\mathrm{c}}$ \\ a University of Geneva, Switzerland \\ b VU University Amsterdam, The Netherlands \\ c University of Lausanne, Switzerland
}

\section{H I G H L I G H T S}

- Collective responsibility increases support for collective punishment.

- This effect is stronger for democratic groups, as compared to nondemocratic groups.

- The value of democracy creates higher expectations for democratic groups.

- Violated expectations decrease group value, increasing punishment.

\section{A R T I C L E I N F O}

\section{Article history:}

Received 29 July 2013

Revised 29 July 2014

Available online 7 September 2014

\section{Keywords:}

Collective responsibility

Collective punishment

Democracy

Expectancy violation

Value

\begin{abstract}
A B S T R A C T
What factors determine the willingness to inflict collective punishment upon a group for a misdeed committed by individual group members? This research investigates the effect of collective responsibility shared among group members and the moderating effect of the group's political organization (democratic vs. nondemocratic). Hypothesizing that moral accountability should be greater for democratic offender groups compared to nondemocratic groups, five experiments showed that the positive effect of collective responsibility on support for collective punishment (Experiment 1) was stronger for democratic groups than for nondemocratic groups (Experiments 2-5). A sixth experiment revealed that the moral and social value ascribed to democracy led to higher expectations towards democratic groups, resulting in negative perceptions of the democratic offender group and ultimately in increased collective punishment. The results are discussed in terms of defense strategies of democratic values. (C) 2014 Elsevier Inc. All rights reserved.
\end{abstract}

In his "Letter to America”, Osama Bin Laden (2002) claimed that:

America is the land of freedom .... Therefore, the American people are the ones who chose their government by way of their own free will, a choice which stems from their agreement to its policies .... This is why the American people cannot be innocent of all the crimes committed by Americans ... against us.

Offender responsibility is a central determinant of retributive judgments (e.g., Darley \& Pittman, 2003; Darley \& Schultz, 1990; Feather, 1996; Miller, 2001; Schultz \& Schleifer, 1983; Vidmar \& Miller, 1980). This is why the extension of a punishment from an actual offender to his or her group is often seen as illegitimate, given that innocent people should not be punished for a wrongdoing perpetrated by others.

\footnotetext{
Author's note: This research was supported by the Swiss National Science Foundation (grant number: 100011-118192).

* Corresponding author at: VU University Amsterdam, Department of Social and Organizational Psychology, Van der Boechorststraat 1, 1081 BT Amsterdam, The Netherlands.

E-mail address: A.Pereira@vu.nl (A. Pereira).
}

Nonetheless, collective punishments are common in social life (Heckathorn, 1988; White, 1994; Whitmeyer, 2002), for instance in schools, the military, and other institutions. As shocking as the abovementioned quote may sound, Bin Laden justified the 9/11 attacks on the basis of the United States' democratic system. This example suggests that the link between collective punishment and collective responsibility might be more complex, and depend on factors such as the group's political organization. The present research sets out to provide a better understanding of this phenomenon by investigating whether perceptions of collective responsibility shape support for collective punishment to a greater extent for democratic groups than for nondemocratic ones.

We contend that collective punishment depends not only on what group members actually did (i.e., on how responsible they are for the offense), but also on who they are (i.e., on the group's characteristics). We argue that whereas democratic groups enjoy greater social value than nondemocratic ones, this value could backlash when it is tarnished by a misdeed that holds the group accountable. Therefore, democratic groups should be punished more harshly under conditions of collective 
responsibility, not necessarily because they are seen as more responsible due to being democratic, but rather because such behavior clashes with expectations held towards such a valued group.

\section{Collective punishment and collective responsibility}

We define collective punishment as the negative treatment inflicted by authorities or by an outgroup upon an entire social group, in reaction to an offense committed by one or some of its members (Falomir-Pichastor, Staerklé, Depuiset, \& Butera, 2007). Even if a collective punishment may be perceived as a legitimate means for deterrence and prevention purposes (Darley \& Pittman, 2003; Heckathorn, $1988,1990)$, it targets people who did not directly perpetrate the offense and are punished merely because they belong to the same group as the culprits. Thus, collective punishment is at odds with the individual responsibility principle that constitutes the basis of criminal law and states that punishment should be proportionate to guilt (Carlsmith, Darley, \& Robinson, 2002; Carlsmith, 2008; Darley, 2002; Hart, 1968; Kant, 1952/1790; Piaget, 1932). Collective punishment is even prohibited by the Geneva 1949 Conventions (art. 33 from the Fourth Geneva Convention, "1949 Conventions, additional protocols, their commentaries”, 1949).

The willingness to punish a group should nevertheless increase as the ascription of collective responsibility increases (e.g., Schultz \& Schleifer, 1983). Collective responsibility refers to the ascription of responsibility to an entire group (Feinberg, 1968; Lickel, Schmader, \& Hamilton, 2003; see May, 1987), because its members have committed a wrongdoing (causal responsibility). But collective responsibility can also be ascribed when group members do not have a direct causal role in the wrongdoing and therefore remain technically innocent (moral responsibility; Zimmermann, Abrams, Doosje, \& Manstead, 2011), a situation that constitutes the focus of the present research. Somewhat surprisingly, only a few studies have examined the link between collective responsibility and collective punishment. One study showed that the attribution of moral collective responsibility was indeed positively related to collective punishment (Falomir-Pichastor et al., 2007). In a similar vein, vicarious punishment (a form of collective punishment in which a group member other than the original offender is targeted by retaliatory punishment) was correlated to perceptions of moral responsibility, but only when it was measured after the assignment of vicarious punishment (Cushman, Durwin, \& Lively, 2012).

By experimentally studying this issue, the present research aims to fill this gap and provide a better understanding of the conditions under which collective responsibility influences the willingness to punish a group for the misdeed of its individual members. We first show that collective responsibility increases support for collective punishment. Second, we contend that the extent to which collective responsibility affects collective punishment depends on the group's political organization: collective responsibility of democratic groups, as opposed to nondemocratic responsibility, leads to a greater increase in support for collective punishment.

\section{Democratic versus nondemocratic groups}

Past research has demonstrated that democracy provides value to innocent members of democratic groups, thereby protecting them from bad treatment. As a result, aggressive acts against a group are perceived as more legitimate when the perpetrator group is democratic rather than nondemocratic and the victim group is nondemocratic (Falomir-Pichastor, Staerklé, Depuiset, \& Butera, 2005). In addition, democratic groups are less collectively punished for such a misdeed as compared to nondemocratic groups (Falomir-Pichastor et al., 2007). Similar findings have also been shown in the context of alleged interstate armed conflicts (Falomir-Pichastor, Pereira, Staerklé \& Butera, 2012; Falomir-Pichastor, Staerklé, Pereira \& Butera, 2012). This leniency effect has been shown to emerge as a function of the value ascribed to democracy (Pereira, Falomir-Pichastor, Berent, Staerklé, \& Butera, 2014) and to be mediated by the perceived value of the offender group (Falomir-Pichastor et al., 2007). Overall these findings demonstrate that the value of democracy infuses retributive judgments in such a way that people show more lenient judgments towards democratic (vs. nondemocratic) groups.

In the present research, we argue that democratic groups are not always protected in retributive judgments. Given that democratic groups are more valued by default and are expected to organize and resolve conflicts in a peaceful way (Staerklé, Clémence, \& Doise, 1998; see also Healy, Hoffman, Beer, \& Bourne, 2002), and that peaceful and honest acts are more valued than aggressive and dishonest acts (Feather, 1999), people might establish higher standards of conduct for democratic than for nondemocratic groups (e.g., Doyle, 1983). Expectancyviolation theory suggests that, when an individual's characteristic or behavior deviates from held expectations, subsequent perceptions of that individual are polarized, becoming more positive or more negative according to the direction of the expectancy violation (Jussim, Coleman, \& Lerch, 1987). As a consequence, the wrongful behavior of a valued democratic group should violate people' expectations towards such groups to a larger extent than that of nondemocratic groups. Such expectancy violation should result in a reduction of the value ascribed to the perpetrator group, which in turn should lead to a stronger willingness to see that group punished.

Indirect evidence for such a proposition can be found in research investigating evaluations and treatments of valued people, such as ingroup members or group leaders. These are generally more positive as compared to those of non-valued people, but the reverse is also observed. When it comes to punishment, more negative treatments of valued people have been shown to originate from perceptions of expectancy violations (Biernat, Vescio, \& Billings, 1999; Karelaia \& Keck, 2013). In line with this reasoning, the subjective group dynamics model (Marques, Abrams, Paez, \& Martinez-Taboada, 1998; Marques, Abrams, \& Serôdio, 2001) suggests that the motivation to preserve a positive image of one's group and its core values can either lead to a more lenient ingroup punishment (in line with the ingroup bias hypothesis; Tajfel \& Turner, 1986; see also Lieberman \& Linke, 2007) or to a more severe one that aims at the symbolic exclusion of the offending ingroup member from the group (in line with the black sheep hypothesis, Marques \& Paez, 1994; see also Kerr, Hymes, Anderson, \& Weathers, 1995). The emergence of one or the other pattern depends on several factors either related to the offense (Karelaia \& Keck, 2013) or to the offender (Gollwitzer \& Keller, 2010; Iyer, Jetten, \& Haslam, 2012; Okimoto \& Wenzel, 2010). In particular, more favorable ingroup judgments are observed when the fellow group member's wrongdoing can be minimized because of the absence of certainty regarding the offender's guilt, but harsher judgments are observed when offender responsibility is unambiguous (van Prooijen, 2006, 2010), consistent with an expectancy violation explanation.

Hence, it appears that the effects of responsibility on punishment are stronger for valued than for devalued people, in line with our rationale concerning democratic and nondemocratic groups. In particular, we want to make clear that we expect such effect to appear above and beyond the potential effect of a greater perceived collective responsibility for democratic groups: At an equivalent high level of collective responsibility, a misdeed committed by a democratic group member should be punished more harshly as compared to that of a nondemocratic group member. Accordingly, in the present research we also examine whether the effect of democratic vs. nondemocratic group organization on support for collective punishment predicted at high levels of collective responsibility is associated with increased expectancy violation and a subsequent decrease in group value.

\section{Overview and hypotheses}

The present research investigates the effect of perceived collective responsibility and group political structure on judgments of collective 
punishment. We first predict that support for collective punishment increases as perceived collective responsibility of the offender group does (Hypothesis 1). We also predict the political organization of the offender group to moderate this effect (Hypothesis 2), such that the effect of collective responsibility on support for collective punishment is stronger for democratic than for nondemocratic offender groups. Finally, when a democratic group is held collectively responsible for an offense, we predict that the value ascribed to democracy increases perceptions of expectancy violation that consequently lead to a reduction in the ascription of value to this group and thus to an increase of collective punishment (Hypothesis 3). Such indirect effects are hypothesized to be specific for democratic groups, and should not be evidenced among nondemocratic groups.

Experiment 1 tested Hypothesis 1, and Experiments 2-5 the first two hypotheses by manipulating collective responsibility and group political organization. A meta-analysis then tests the overall simple effects evidenced in Experiments 2-5. Experiment 6 focused on high collective responsibility conditions in order to test Hypothesis 3 . In all studies, participants were presented with an offense committed by some members of a group. Subsequently, they were asked to indicate their support for the collective punishment of that group. In the first three experiments, the offense was an act of plagiarism, whereas the other experiments used more violent offenses such as aggressive acts during an ice hockey game (Experiments $4 \& 6$ ) and acts of vandalism (Experiment 5). Support for collective punishment was the main dependent variable in all experiments. Experiment 6 additionally assessed perceived expectancy violations and offender group value, and support for the group leader punishment as an additional dependent variable.

\section{Experiment 1}

Experiment 1 was conducted using a case of plagiarism and varying levels of collective responsibility in order to verify that collective responsibility increases collective punishment.

\section{Sample and procedure}

Thirty-nine university students were individually recruited in the facilities of a large Swiss University ( 22 women and 17 men). Their ages ranged from 18 to 31 years $(M=22.21, S D=2.76)$. Participants were randomly assigned to one of two experimental conditions (collective responsibility: low versus high).

Participants were given a booklet in which they read that the experimenters were interested in their opinion concerning a dilemma. They were told that, during a seminar, a student group was evaluated collectively through a group assignment. However, one of the students found an article on the Internet that was highly relevant for their work and, in order to maximize the group's chances of success, included some important sections of this article in their paper before handing it to the professor. Given that this is an obvious case of plagiarism, that the assignment was a collective task, and that the group needed to be evaluated collectively, participants were asked whether the entire group should be punished as a consequence of this misdeed.

\section{Independent variable}

Collective responsibility was experimentally manipulated. In the low collective responsibility condition, the plagiarizer had not informed the other group members who remained unaware of the plagiarism. In the high collective responsibility condition, the plagiarizer had informed the others about his deeds before handing in the report. All group members were therefore aware of the plagiarism, although only one of them actually committed the misdeed, and none reacted to it.

\section{Manipulation check}

Five items measured perceived collective responsibility. 'To what extent do you think that the students who did not commit the plagiarism ...?': were responsible of the assignment, were aware of the plagiarism, passively supported the plagiarizer, collaborated in some way with the plagiarizer to commit the plagiarism, are co-responsible for the plagiarism (from 1 'not at all' to 7 'absolutely'; $\alpha=.79$ ).

\section{Collective punishment}

After the description of the plagiarism, participants were reminded that the assignment was a collective one and that the professor needed to evaluate the group as a whole. Support for collective punishment was then assessed through one item: 'Beyond the punishment applied to the plagiarizer, to what extent should the entire group be punished?' (from 1 'not at all' to 7 'harshly').

\section{Results and discussion}

All descriptive statistics are displayed in Table 1 (manipulation checks) and Table 2 (support for collective punishment). As expected, the perception of collective responsibility was higher in the high collective responsibility condition than in the low collective responsibility condition, $p<.001, d=1.49$, indicating that the experimental manipulation worked as expected. Moreover, support for collective punishment was higher when collective responsibility was high rather than low, $p=.002, d=1.07$. This first experiment experimentally showed that collective responsibility increased support for collective punishment.

\section{Experiment 2}

Experiment 2 additionally manipulated the plagiarizer's group political organization. In addition to the effect of collective responsibility, we expected a collective responsibility by offender group political organization interaction effect on support for collective punishment: The effect of collective responsibility should be stronger for democratic groups than for nondemocratic ones.

\section{Method}

\section{Sample and design}

Ninety-five students of a large Swiss university ( 40 women and 55 men; ages ranging from 18 to 32 years, $M=23.37, S D=2.3$ ) were recruited on campus and asked to answer a written questionnaire. They were randomly assigned to one of four conditions of a 2 (collective responsibility: low, high) $\times 2$ (group political organization: democratic, nondemocratic) experimental design. As this experiment was very similar to Experiment 1, only differences will be mentioned hereafter.

\section{Independent variables}

We manipulated offender group political organization by initially informing participants that a professor investigated how student groups self-organize in order to carry out collective tasks such as writing up group assignments. His studies allegedly evidenced two main types of groups: egalitarian and hierarchical. Participants read that "Some groups function in an egalitarian way. They collectively designate a student as the group 'leader' who is responsible for the coordination of the group's work. Important decisions are made (and disagreements are resolved) during discussions in which all group members participate. Some other groups function in a hierarchical way. A student spontaneously assumes the coordination of group work. Important decisions are made (and disagreements are resolved) by this 'leader' without discussion with other group members".

After that, participants were told that the current research focused on their opinion concerning a situation that occurred during a seminar 
Table 1

Marginal means and standard deviations for manipulation checks in Experiments 1 through 5.

\begin{tabular}{|c|c|c|c|c|c|c|c|c|c|c|}
\hline & \multirow{2}{*}{\multicolumn{2}{|c|}{ Experiment 1}} & \multicolumn{2}{|c|}{ Experiment 2} & \multicolumn{4}{|c|}{$\begin{array}{c}\text { Experiment } 3 \quad \text { Experiment } 4 \\
\text { Political organization } \\
(\mathrm{D}=\text { democratic, } \mathrm{ND}=\text { nondemocratic })\end{array}$} & \multicolumn{2}{|c|}{ Experiment 5} \\
\hline & & & $\mathrm{D}$ & ND & $\mathrm{D}$ & ND & $\mathrm{D}$ & ND & $\mathrm{D}$ & ND \\
\hline \multirow[t]{3}{*}{ Group political organization } & & & $\begin{array}{c}3.87 \\
(2.19)\end{array}$ & $\begin{array}{c}5.34 \\
(1.97)\end{array}$ & $\begin{array}{c}3.09 \\
(2.26)\end{array}$ & $\begin{array}{c}5.55 \\
(1.70)\end{array}$ & $\begin{array}{c}2.56 \\
(2.12)\end{array}$ & $\begin{array}{c}6.13 \\
(1.43)\end{array}$ & - & - \\
\hline & \multicolumn{10}{|c|}{ Collective responsibility } \\
\hline & Low & High & Low & High & Low & High & Low & High & Low & High \\
\hline Perceived collective responsibility & $\begin{array}{c}3.43 \\
(1.08)\end{array}$ & $\begin{array}{c}4.93 \\
(0.93)\end{array}$ & $\begin{array}{c}3.00 \\
(1.07)\end{array}$ & $\begin{array}{c}5.05 \\
(1.18)\end{array}$ & $\begin{array}{c}3.01 \\
(1.26)\end{array}$ & $\begin{array}{c}3.75 \\
(1.40)\end{array}$ & $\begin{array}{c}4.44 \\
(.90)\end{array}$ & $\begin{array}{c}5.06 \\
(1.01)\end{array}$ & $\begin{array}{c}3.02 \\
(1.11)\end{array}$ & $\begin{array}{c}3.78 \\
(1.18)\end{array}$ \\
\hline Group entitativity & & & - & - & $\begin{array}{l}3.63 \\
(.93)\end{array}$ & $\begin{array}{c}4.32 \\
(1.02)\end{array}$ & - & - & - & - \\
\hline
\end{tabular}

Note. Dashes (-) refer to data that is not reported because it was not measured.

taught by the same professor. The description of the plagiarism case contained the manipulation of the political organization of the group: "By the way, the group in question was an egalitarian [a hierarchical] group."

\section{Manipulation checks}

Perceived collective responsibility ( $\alpha=.84$ ) was measured as in the pilot study. A final question assessed whether the group political organization was correctly perceived: "To what extent was the group in question ...?": from $1=$ 'egalitarian' to $7=$ 'hierarchical'.

Results

A 2 (collective responsibility: low, high) by 2 (political organization: democratic, nondemocratic) ANOVA was performed on perceptions of collective responsibility and group political organization (manipulation checks), and on support for collective punishment (dependent variable). All descriptive data are provided in Tables 1 (manipulation checks) and 2 (support for collective punishment), and Fig. 1 displays the results on support for collective punishment.

\section{Manipulation checks}

Collective responsibility was perceived as higher in the high collective responsibility condition than in the low collective responsibility, $F(1,90)=86.64, p<.001, \eta_{\mathrm{p}}^{2}=.49$. Additionally, the political organization by collective responsibility interaction effect was significant, $F(1,90)=11.38, p=.001, \eta_{\mathrm{p}}^{2}=.11$. The effect of collective responsibility was significant both in the democratic condition, $t(90)=8.76, p<.001$, and in the nondemocratic condition, $t(90)=4.29, p<.001$. However, in the low responsibility condition, perceived responsibility tended to

Table 2

Means and standard deviations for support for collective punishment in Experiments 1 through 5 as a function of collective responsibility (low vs. high) and group political organization (democratic vs. nondemocratic). Means not sharing subscripts differ at least at $p<.05$.

\begin{tabular}{|c|c|c|c|c|}
\hline & & \multicolumn{3}{|c|}{ Collective responsibility } \\
\hline & & Low & & High \\
\hline \multirow[t]{5}{*}{ Experiment 1} & & $2.78(1.48)^{\mathrm{a}}$ & & $4.33(1.43)^{\mathrm{b}}$ \\
\hline & \multicolumn{4}{|c|}{ Group political organization } \\
\hline & \multicolumn{2}{|c|}{ Democratic } & \multicolumn{2}{|c|}{ Nondemocratic } \\
\hline & \multicolumn{4}{|c|}{$\overline{\text { Collective responsibility }}$} \\
\hline & Low & High & Low & High \\
\hline Experiment 2 & $2.45(1.40)^{\mathrm{a}}$ & $5.00(1.61)^{b}$ & $2.65(1.50)^{\mathrm{a}}$ & $3.88(1.51)^{c}$ \\
\hline Experiment 3 & $2.5(1.69)^{\mathrm{a}}$ & $3.54(2.02)^{\mathrm{b}}$ & $2.58(1.35)^{\mathrm{a}}$ & $2.24(1.45)^{\mathrm{a}}$ \\
\hline Experiment 4 & $4.03(1.40)^{a}$ & $5.77(1.34)^{\mathrm{b}}$ & $5.05(1.70)^{b}$ & $5.19(1.62)^{b}$ \\
\hline Experiment 5 & $3.16(1.26)^{a}$ & $3.74(1.1)^{\mathrm{b}}$ & $3.73(1.22)^{b}$ & $3.22(.92)^{\mathrm{a}}$ \\
\hline
\end{tabular}

be higher for the nondemocratic group than for the democratic group, $t(90)=1.68, p=.096$, whereas the reverse effect was significant in the high responsibility condition, $t(90)=3.15, p=.002$. In other words, the effect of collective responsibility was polarized for democratic groups. The main effect of group political organization was not significant $(p=.38)$.

Concerning the manipulation of group political organization, the offender group was, as expected, perceived as more hierarchical in the nondemocratic group condition than in the democratic group condition, $F(1,91)=11.68, p=.001, \eta_{\mathrm{p}}^{2}=.11$. Neither the collective responsibility nor the interaction effects were significant (all ps $>.84$ ).

\section{Collective punishment}

A more severe collective punishment was overall supported when collective responsibility was high rather than low, $F(1,90)=35.56$, $p<.001, \eta_{p}^{2}=.29$. Furthermore, the predicted collective responsibility by group political organization interaction effect was significant, $F(1,90)=4.44, p=.038, \eta_{\mathrm{p}}^{2}=.05$ : The effect of collective responsibility was stronger when the offender group was democratic, $t(90)=$ $-5.63, p<.001$, rather than nondemocratic, $t(90)=-2.85, p<.005$. In addition, at high levels of collective responsibility, participants inflicted a more severe collective punishment upon the democratic group than the nondemocratic group, $t(90)=2.64, p=.01$. The main effect of group political organization was not significant $(p=.148)$.

\section{Discussion}

This experiment first showed that collective punishment increased as collective responsibility increased. Results also provide support for the second hypothesis: the effect of collective responsibility on collective punishment was stronger for the democratic offender group than for the nondemocratic one. Moreover, offender group political organization moderated the effect of collective responsibility on perceived collective responsibility in such a way that the democratic group organization polarized the effect of the experimentally induced collective responsibility. This effect is in line with our theoretical assumption as perceptions of responsibility are more meaningful for actions committed by democratic groups as compared to nondemocratic ones. However, this effect constitutes a methodological limitation that we address in the next experiment by manipulating collective responsibility without providing explicit information about the group behavior regarding the offense. Additionally, the potential mediating effect of perceptions of collective responsibility is investigated in Experiment 6 (see below).

\section{Experiment 3}

In order to manipulate collective responsibility without explicitly providing information about group members' implication in the plagiarism act, this study focused on group entitativity (Yzerbyt, Judd, \& 


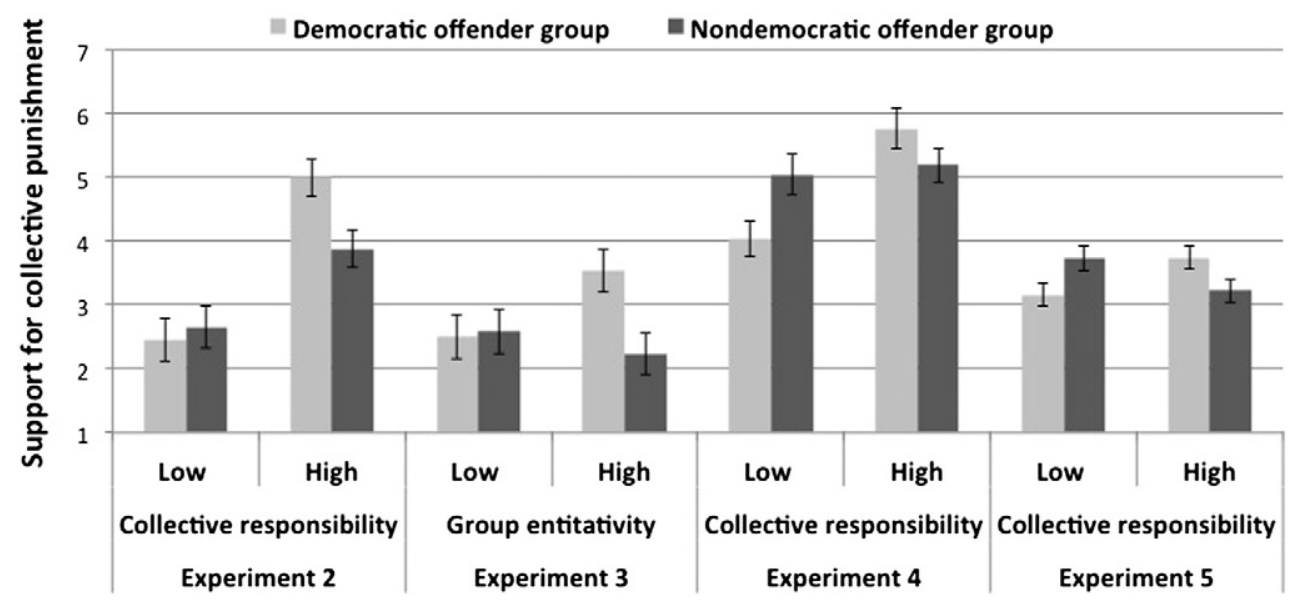

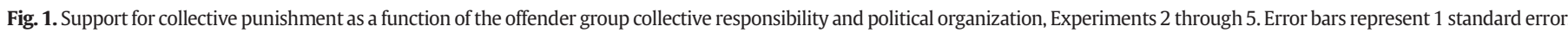

Corneille, 2004). Research has shown that group members' level of intimacy, common tasks, shared social category membership and overall association result in different levels of perceived group entitativity (Lickel et al., 2000). Furthermore, group entitativity increases the attribution of shared responsibility for an offender's action (Lickel et al., 2003) and of ensuing collective blame (Denson, Lickel, Curtis, Stenstrom, \& Ames, 2006). Finally, group entitativity also increases the propensity of retaliating against an outgroup following a hostile act of one of its members (i.e., vicarious retribution; Gaertner \& Iuzzini, 2005; Gaertner, Iuzzini, \& O'Mara, 2008; Lickel, Miller, Stenstrom, Denson, \& Schmader, 2006; Stenstrom, Lickel, Denson, \& Miller, 2008), the propensity of inflicting collective treatments in general (Alter \& Darley, 2009), and of collective punishment in particular (Newheiser, Sawaoka, \& Dovidio, 2012). Accordingly, we reasoned that group entitativity might constitute an indirect way to experimentally manipulate collective responsibility without explicitly relating the group to the offense. We expected high levels of group entitativity to increase perceived collective responsibility independently of the group political organization. Accordingly, in this experiment, we tested our second hypothesis expecting a group entitativity by political organization interaction effect.

Method

\section{Sample and design}

Ninety-seven students of a large Swiss University ( 52 women and 45 men; ages ranging from 19 to 31 years, $M=22.79, S D=2.26$ ) recruited in the university facilities were randomly assigned to one of the four experimental conditions in a 2 (group entitativity: low, high) $\times 2$ (group political organization: democratic, nondemocratic) design. Again, the same materials were used (plagiarism case). Therefore, we will hereafter only describe the differences with previous experiments.

\section{Independent variables}

We manipulated offender group political organization with the same materials and procedure as in Experiment 2, and group entitativity was manipulated immediately thereafter. Following Lickel et al. (2000), the low group entitativity condition read that "members of this group were students who had not found a group yet, and gathered together randomly", whereas the high entitativity condition stated that "members of this group were all part of the same football team, and gathered together out of affinity".

\section{Manipulation checks}

Five items measured perceived group entitativity: Members of this group may function in the same way across different situations, have similar opinions, organize in a different way (reversed score), be similar to each other, and function differently from each other (reversed score) $(\alpha=.66)$. Perceived collective responsibility was assessed as in Experiment $2(\alpha=.81)$.

Results

Manipulation checks

Perceived group entitativity was higher in the high entitativity condition than in the low entitativity condition, $F(1,93)=11.59, p=.001$, $\eta_{\mathrm{p}}^{2}=.11$. Neither the political organization main effect nor the interaction effect was significant ( $p$ 's $>.72$ ). Furthermore, the offender group was perceived as more collectively responsible in the high entitativity condition than in the low entitativity condition, $F(1,93)=7.33, p=$ $.008, \eta_{\mathrm{p}}^{2}=.07$. Neither the group political organization main effect nor the interaction effect was significant ( $p s>.62$ ). Overall, these results indicate that this new manipulation was successful.

The offender group was seen as more hierarchical in the nondemocratic group condition than in the democratic group condition, $F(1,92)=37.24, p<.001, \eta_{\mathrm{p}}^{2}=.29$. The main effect of group entitativity was not significant $(p=.29)$, and the interaction effect was marginally significant, $F(1,92)=3.68, p=.058, \eta_{\mathrm{p}}^{2}=.04$.

\section{Collective punishment}

Results showed a marginally significant main effect of group political organization, $F(1,93)=3.31, p=.072, \eta_{\mathrm{p}}^{2}=.03$. The main effect of entitativity was not significant $(p=.30)$, but the predicted group political organization by group entitativity interaction effect was, $F(1,93)=$ 4.28, $p=.041, \eta_{\mathrm{p}}^{2}=.04$ : the democratic offender group was more severely punished in the high entitativity condition than in the low entitativity condition, $t(93)=2.19, p=.031$, whereas the nondemocratic offender group was punished to the same extent in both conditions $(p=.47)$. At high levels of group entitativity, support for collective punishment was higher for the democratic group than for the nondemocratic group, $t(93)=2.76, p=.003$, whereas no difference emerged when group entitativity was low $(p=.86)$.

\section{Discussion}

This experiment used a different operationalization of collective responsibility by providing only information on group entitativity. As expected, and consistent with prior research (Lickel et al., 2000), a highly cohesive group (a sports team) was perceived as having higher levels of entitativity and as being more collectively responsible for its members' behavior than a randomly formed group. Furthermore, the predicted group entitativity by group political organization interaction effect was significant: democratic groups were more harshly punished when they were highly entitative (i.e., highly collectively responsible), but 
no significant difference was observed as a function of entitativity when the group was nondemocratic.

\section{Experiment 4}

In order to provide convergent validity to our findings, we conducted another experiment using a different misdeed: an aggression perpetrated by fan club members during an ice-hockey game. With this new paradigm, we again manipulated collective responsibility in a straightforward way. Group political organization was also manipulated, and support for collective punishment was again our main dependent variable. In line with our second hypothesis, we predicted a collective responsibility by group political organization interaction effect on support for collective punishment.

\section{Method}

\section{Participants and design}

Participants were recruited in several public areas in Switzerland (on the University campus, in train stations, etc.). Out of the 107 participants, 61 were female (57\%). Their ages ranged from 18 to 82, with a mean of 30.62 ( $S D=14.15)$. Fifty of them were students. They were randomly assigned to one of the four experimental conditions in a 2 (collective responsibility: low, high) $\times 2$ (group political organization: democratic, nondemocratic) design.

\section{Procedure}

Participants read that a purported professor had observed two types of groups, egalitarian and hierarchical, that were described as in the first two studies. Thereafter, participants read a fictitious scenario describing an incident that occurred during an ice-hockey game: two members of a fan club, taking advantage of the low visibility provoked by smoke devices, threw projectiles at rival fans. As a result, two fans of the opposing team were severely injured.

\section{Independent variables}

The manipulation of offender group political organization was similar to the one used in the previous studies: Participants read that the fan club was organized in an egalitarian versus hierarchical way.

Collective responsibility was manipulated at the moment the aggression was described. Participants read that the police investigated this incident and that their report stated either that the investigation revealed several "contradictory reports, because of which it is not possible to be certain whether the other members of the group actually contributed to the aggression by facilitating or encouraging it" (low responsibility condition), or "consistent reports making it clear that the other members of the group contributed to the aggression by facilitating and encouraging it" (high responsibility condition).

\section{Manipulation checks}

As a measure of perceived collective responsibility adapted to the new scenario, participants indicated the extent to which they perceived that other group members: knew who the aggressors were, passively supported the aggression, facilitated the aggression, encouraged the aggression, should have prevented the aggression, should have done everything to identify and denounce the aggressors, and are co-responsible for the aggression on a one to seven scale $(1=$ not at all, $7=$ completely; $\alpha=.77)$. In addition, on a seven-point bipolar scale from egalitarian to hierarchical, participants indicated the type of organization of the fan club that they just read about.

\section{Collective punishment}

Support for collective punishment was measured with one item on a seven-point scale ( $1=$ not at all, $7=$ completely): to what extent should all other group members be punished in one way or another?
Results

\section{Manipulation checks}

Results revealed that collective responsibility was perceived to be higher in the high responsibility condition than in the low responsibility condition, $F(1,102)=10.19, p<.002, \eta_{\mathrm{p}}^{2}=.09$. No other effects were significant (all ps $>.28$ ). Democratic groups were perceived to be more egalitarian than nondemocratic groups, $F(1,102)=106.73$, $p<.001, \eta_{\mathrm{p}}^{2}=.51$. No other effects were significant (all ps $>.15$ ).

\section{Support for collective punishment}

Support for collective punishment was higher at high levels of collective responsibility $(M=5.43, S D=1.52)$ than at low levels $(M=4.46, S D=1.60), F(1,102)=9.81, p=.002, \eta_{p}^{2}=.09$. The predicted interaction effect was significant as well, $F(1,102)=7.07, p=$ $.009, \eta_{\mathrm{p}}^{2}=.07$. The democratic offender group was more severely punished at high than at low levels of collective responsibility, $t(102)=4.07, p<.001$, whereas this difference was not observed for the nondemocratic offender group, $p=.74$. In addition, when collective responsibility was low, the nondemocratic group was more harshly punished than the democratic group, $t(102)=2.37, p<.02$, but no statistically significant difference appeared when collective responsibility was high, $t(102)=1.39, p<.17$.

\section{Discussion}

The findings of Experiment 4 showed again that the predicted collective responsibility by group political organization interaction was significant. A more severe treatment of democratic groups appeared in the high responsibility condition as compared to the low responsibility condition, whereas this was not the case for nondemocratic groups.

\section{Experiment 5}

To provide supplementary external validity to the results obtained so far, Experiment 5 examined the effect of collective responsibility and group political organization in a paradigm describing a case of vandalism (see Falomir-Pichastor et al., 2007). We additionally included a more reliable measure of support for collective punishment, replacing the one-item measure with a multi-item scale.

\section{Method}

\section{Participants}

One hundred and forty-eight participants from a large Swiss university (76 women and 72 men; ages ranging from 18 to 64 years, $M=$ $31.03, S D=9.79$ ) were recruited in university facilities and randomly assigned to one of four experimental conditions of a 2 (collective responsibility: low, high) by 2 (group political organization: democratic, nondemocratic) design.

\section{Procedure}

The paradigm is similar to that used in Falomir-Pichastor et al. (2007). Participants were informed that scientific research had investigated spontaneous group organization among young people participating in summer camps and evidenced two main types of internal organization of groups: hierarchical and egalitarian that were described as in the previous studies.

Participants were then told that the experimenters were interested in their opinion concerning an incident that supposedly occurred during one of these camps. The residents of a nearby village complained about the presence of noisy teenagers and asked the authorities to shut down the camp. A few days later, two group members went to the village, sprayed graffiti on facades, broke windows, insulted a resident and stole items from the local supermarket. The culprits, hooded, 
could not be identified, but it was clear that they belonged to the summer camp.

\section{Independent variables}

Offender group political organization was manipulated when the vandalism incident was described: Participants read that the group was egalitarian or hierarchical.

Collective responsibility was manipulated by telling participants that the wrongdoers were not identified either because the other members of the group did not know their identity (low responsibility condition) or because they knew their identity, but decided to cover up for them (high responsibility condition).

\section{Manipulation check}

Six items measured perceived collective responsibility: The other group members directly contributed to the aggression, indirectly contributed to the aggression, knew the offenders' intention, could have prevented the offense, should have known the offenders' intention, and knew the offenders' identity but would not denounce them $(1=$ not at all, $7=$ completely; $\alpha=.81$ ). No manipulation check was introduced for the group political organization in the present study, given that this manipulation proved itself efficient in the previous studies.

\section{Collective punishment}

Participants were finally asked to indicate their support for collective punishment with 8 items. Given that the actual wrongdoers were not identified, participants were asked to indicate the extent to which all members of the group should: give back the stolen money, publicly apologize, do public service in the village, pay a compensation to the village, be prohibited to leave their tent, leave the camp before its end, be prohibited to participate in next camps, and be deprived from sport and play activities. All items were aggregated into a measure of support for collective punishment $(1=$ not at all, $7=$ absolutely; $\alpha=.75)$.

\section{Results}

\section{Manipulation check}

In the low responsibility condition, the offender group was perceived as less responsible than in the high responsibility condition, $F(1,144)=16.18, p<.001, \eta_{\mathrm{p}}^{2}=.10$, indicating that our manipulation was successful. The main effect of the offender group political organization was marginally significant, $F(1,144)=3.37, p=.069, \eta_{\mathrm{p}}^{2}=.02$, and the interaction term was not $(p=.86)$.

\section{Support for collective punishment}

Neither the main effect of collective responsibility nor that of group political organization was significant ( $p s>.84$ ), but the predicted collective responsibility by political organization interaction effect was, $F(1,144)=8.70, p=.004, \eta_{\mathrm{p}}^{2}=.06$. As predicted, the democratic offender group was more strongly punished in the high responsibility condition than in the low responsibility condition, $t(144)=2.97$, $p=.004$. However, surprisingly, the nondemocratic offender group was less punished in the high responsibility condition than in the low responsibility condition, $t(144)=2.72, p=.007$. We additionally observed that in the low responsibility condition, support for collective punishment was higher for the nondemocratic than for the democratic group, $t(144)=2.11, p=.037$, whereas in the high responsibility condition, it was higher for the democratic than the nondemocratic group, $t(144)=-2.06, p=.041$.

\section{Discussion}

The present experiment revealed again a significant offender group political organization by collective responsibility interaction. The democratic group was punished more severely when its collective responsibility was high rather than low, whereas this was not the case for the nondemocratic group.

However, we observed an unexpected effect of collective responsibility for the nondemocratic group that was actually less punished in the high responsibility condition than in the low responsibility condition. This effect is at odds with previous research where responsibility has constantly been related to higher levels of punishment, not lower ones. An explanation for this finding might lie in inferences potentially made by respondents when faced with a collectively responsible nondemocratic group: Collective punishments against nondemocratic groups may be less meaningful in this "covering-the-offenders" scenario (i.e., when group responsibility is high), because the authoritarian functioning of the hierarchical group may lead observers to think that group members were merely complying with their leaders' requests (Milgram, 1974) rather than deliberately refusing to denounce the actual culprits. Further research is needed to better understand this effect.

\section{Meta-analysis}

Across the last four experiments, we observe that democratic groups were less collectively punished than nondemocratic groups at low levels of collective responsibility, whereas they were more punished at high levels of collective responsibility, but these simple effects were not significant in every experiment. Given that $p$-values are likely to vary greatly around a true effect (Lai, Fidler, \& Cumming, 2012), it might well be that these are true effects that simply occasionally don't reach the conventional threshold for significance. In order to provide the most trustworthy result, we conducted two meta-analyses on Experiments 2 through 5 testing the overall significance of the offender group political organization effect on support for collective punishment at low and high collective responsibility levels. Although these specific differences were not directly part of our hypotheses (but are logically derived from our hypotheses), they are theoretically meaningful and interesting, and hence worth investigating further.

\section{Results and discussion}

Following the procedure recommended by Lipsey and Wilson (2001) and Hedges and Olkin (1985), using a fixed-effects model and weighting studies according to sample size, we first calculated each study's effect size and inverse variance weight (see Table 3). We were then able to calculate the average effect size and an associated $p$-value across all studies. Results show that at low levels of collective responsibility, group political organization has a reliable medium size effect on support for collective punishment $(d=.33,95 \%$ confidence interval $[\mathrm{CI}]$ lower limit $[L L]=.06$, upper limit $[U L]=.60, S E=.14, z=2.37$, $p=.018$ ). At high levels of collective responsibility, group political organization also has a reliable medium size effect on support for collective punishment $(d=.46,95 \% \mathrm{CI} L L=.20, U L=.72, S E=.13, z=3.45$, $p<.001$ ). These results allow us to be confident about the existence of these effects: At low levels of collective responsibility, support for collective punishment is lower for democratic than for nondemocratic groups, whereas at high levels of collective responsibility, support for collective punishment is higher for democratic than for nondemocratic groups.

\section{Experiment 6}

We have shown that democratic groups are more punished as a function of their collective responsibility for a misdeed, whereas this is less the case for nondemocratic groups. In addition, democratic groups are less punished than nondemocratic ones at low levels of collective responsibility, and more punished at high levels of collective responsibility. While the difference due to the groups' political organization at low levels of responsibility can easily be explained by the expression of leniency towards valued democratic groups (Falomir-Pichastor 
Table 3

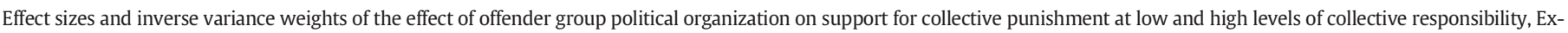
periments 2 through 5 (meta-analysis).

\begin{tabular}{|c|c|c|c|c|}
\hline & \multicolumn{2}{|c|}{ Low collective responsibility } & \multicolumn{2}{|c|}{ High collective responsibility } \\
\hline & Effect size & Inverse variance weight & Effect size & Inverse variance weight \\
\hline Experiment 2 & 0.13 & 10.67 & 0.56 & 12.26 \\
\hline Experiment 3 & 0.05 & 11.99 & 0.57 & 11.76 \\
\hline Experiment 4 & 0.56 & 12.22 & 0.28 & 12.92 \\
\hline Experiment 5 & 0.48 & 16.99 & 0.45 & 18.99 \\
\hline
\end{tabular}

et al., 2007), Experiment 6 was designed to provide evidence of the specific processes accounting for the punishment of such groups at higher levels of collective responsibility. First, we argue that the increase in support for the collective punishment of democratic groups should be observed in particular among people who ascribe a relatively higher social value to democracy. Second, we argue that the higher social value ascribed to democratic groups comes with a price: higher expectations. If a democratic group's conduct is evaluated with a higher standard than a nondemocratic group's conduct, then a misdeed for which the entire democratic group is responsible for (e.g. a misdeed for which it is impossible to exonerate the group for) should represent a violation of these heightened expectations. As a result, at high levels of collective responsibility, the greater punishment of democratic groups as compared to nondemocratic groups should be moderated by the value ascribed to democracy (H3a), and mediated both by the perception of democratic offender group expectancy violation and by the subsequent reduction in the value attributed to this specific democratic offender group (a serial mediation hypothesis - H3b). Such processes should not be observed for nondemocratic groups, which are punished indifferently of their collective responsibility for the misdeed.

Finally, if the predicted effects are indeed related to perceptions of expectancy violation and to value judgments inferred from the group's political organization, we contend that the same processes should apply not only to the group as a whole, but also to the group leader. We hence predicted an interaction effect between the group political organization and respondents' valorization of democracy on support for the group leader punishment (H4a), and a serial mediation effect through group expectancy violation and group value (H4b).

We used the same paradigm as in Experiment 4 (aggressive behavior during an ice-hockey game), manipulated group political organization (democratic, nondemocratic) and kept collective responsibility constant at a high level. In addition to the support for collective punishment, we assessed valorization of democracy as a moderator of the group political organization main effect, perceived expectancy violations and offender group social value as serial mediators, and support for the punishment of the group leader as an additional dependent variable.

We hence tested two serial mediated moderations: under high collective responsibility, the effect of group political organization on support for both collective and leader punishment should be moderated by respondents' valorization of democracy, such that the more people value democracy, the more they should support punishment of the democratic group and the democratic leader, whereas punishment of the nondemocratic group and nondemocratic leader should not differ according to respondents' level of valorization of democracy. Furthermore, these effects should be mediated sequentially by perceived expectancy violations and perceived group value: taking these two variables into account should significantly reduce the moderation effect on support for collective punishment and the indirect effect of these two mediating variables should be significant.

As a concurrent explanation of these processes, we measured collective responsibility and tested it as a mediator of the effect. It would indeed also be possible that, independently of our experimental manipulation, members of democratic groups are simply perceived as globally more collectively responsible than nondemocratic group members, given their participative decision-making procedures, as was observed in the present Experiment 2. Such a perception could explain that collective responsibility has a stronger effect on democratic groups than nondemocratic ones. Although such an understanding was not supported by Experiments 3 to 5, in which no main effect of the group's political organization on collective responsibility was found, this alternative explanation was investigated in the present experiment in order to rule it out more confidently.

\section{Method}

\section{Sample and design}

Participants were 137 adults recruited through Amazon Mechanical Turk and compensated for their participation with USD 0.40. Fifty percent of them were female, their ages ranging from 18 to $80(M=$ $34.27, S D=12.34$ ), and only 2 of them reported not being US citizens (but were originally from India). Participants were randomly assigned to one of the two conditions, where collective responsibility was kept constant at a high level, and the group political organization was manipulated (democratic vs. nondemocratic).

\section{Procedure}

The procedure essentially replicated that from Experiment 4, with the exception that collective responsibility was kept constant at a high level.

\section{Independent variables}

Offender group political organization was manipulated by merely mentioning that the group was identified by the professor as being typically "egalitarian" (= democratic) or typically "hierarchical" (=nondemocratic).

Valorization of democracy was measured with 8 items (see Pereira et al., 2014). Participants were asked to indicate the extent to which they agreed with 8 statements in relation to democracy (e.g., I prefer democracy over other forms of government, I value democracy as a political system, people are happier when living in a democratic country as compared to other forms of government, etc.) on a 1 (not at all) to 7 (absolutely) scale.

\section{Manipulation checks}

Perception of the group political organization was assessed through one item: What was the organization of the group you just read about? $(1$ = hierarchical, 7 = egalitarian $)$.

\section{Dependent variables}

Support for collective punishment was measured through seven items. Participants indicated on a 1 (not at all) to 7 (absolutely) scale the extent to which they considered that all group members should: publicly apologize to the victims, publicly apologize to the sport authorities, complete community service hours in the skating rink, contribute to the victims' medical costs, be prohibited from entering the skating rink, be prohibited from assisting any of their team's future games, and be prohibited from getting together as a fan club.

Support for the leader punishment was measured through the same items as the collective punishment, but participants indicated the 
Table 4

Descriptive statistics and correlations for Experiment 6 variables. ${ }^{*}=p<.01,^{*}=p<.05$.

\begin{tabular}{|c|c|c|c|c|c|c|c|c|c|}
\hline Variable & $M$ & $S D$ & $\alpha$ & 1 & 2 & 3 & 4 & 5 & 6 \\
\hline 1. Valorization of democracy & 5.25 & 1.26 & .93 & & & & & & \\
\hline 2. Expectancy violation & 5.68 & 1.09 & .78 & .04 & & & & & \\
\hline 3. Offender group value & 2.29 & 1.04 & .90 & $-.21^{*}$ & $-.47^{* *}$ & & & & \\
\hline 4. Collective responsibility & 5.36 & 1.18 & .91 & .09 & $.30^{* *}$ & $-.45^{* *}$ & & & \\
\hline 5. Collective punishment & 5.66 & 1.14 & .82 & .14 & $.23^{* *}$ & $-.56^{* *}$ & $.48^{* *}$ & & \\
\hline 6. Leader punishment & 5.78 & 1.20 & .88 & $.21^{*}$ & $.29^{* *}$ & $-.53^{* *}$ & $.54^{* *}$ & $.73^{* *}$ & \\
\hline 7. Group organization & 3.71 & 2.69 & - & .07 & .04 & .12 & .04 & -.12 & $-.24^{* *}$ \\
\hline
\end{tabular}

extent to which they thought those punishments should be applied to the group leader. The last item was adapted and stated: "be excluded from the fan club".

\section{Mediators}

Collective responsibility. Participants indicated on a 1 (not at all) to 7 (absolutely) scale the extent to which they considered that the group members other than the aggressors: knew the aggressors' identity, passively supported the aggression, encouraged the aggression, should have prevented the aggression, are accountable for what happened, somehow contributed to the aggression, are co-responsible for the aggression, should be held morally responsible for what happened.

Expectancy violation. Participants were asked to indicate (compared to other ice hockey fan clubs): did the group's behavior match what you would expect (reverse coded), did the group's behavior violate any expectations you might have had about how fan-club supporters should behave, how typical was the group's behavior (reverse coded), should they have known better, and if participants expected more from this group. These 5 items were aggregated into a measure of expectancy violation (from 1 - not at all to 7 - absolutely).

Offender group value. Participants were asked to indicate, on a 1 (not at all) to 7 (absolutely) scale, the extent to which they considered the members of this fan club as: moral, bad (reverse coded), fair, honest, respectful, good people, violent (reverse coded), and trustworthy.

Results

Descriptive statistics, alpha values and correlations for all measured variables are provided in Table 4. In preparation for the test of our full model, all variables (manipulation checks, dependent variables, and mediators) were separately regressed on a model including group political organization (democratic $=-1$, and nondemocratic $=1$ ), valorization of democracy (standardized score), and the interaction term between these two variables.

\section{Manipulation checks}

The overall model tested on perceived group political organization was significant, $F(1,116)=56.02, p<.001, R^{2}=.59$, as was the main effect of group political organization, $B=-2.07, t(116)=12.91$, $p<.001$. This effect revealed that in the nondemocratic group condition $(M=5.68, S E=.22)$, the group was perceived as more hierarchical than in the democratic group condition $(M=1.53, S E=.23)$, indicating that the manipulation of group political organization was effective. No other effects were significant ( $p s>.6$ ).

\section{Dependent variables}

On support for collective punishment, the overall model was significant, $F(1,116)=2.78, p=.044, R^{2}=.07$, as was the predicted interaction effect, $B=-.23, t(116)=-2.09, p=.039$. No other effects were significant, although the effect of valorization of democracy was marginally significant, $B=.20, t(116)=1.85, p=.067$. Simple slope analyses indicated that valorization of democracy indeed increased support for collective punishment when the offender group was democratic, $B=.41, t(116)=2.68, p=.009$, but not when it was nondemocratic, $B=-.03, t(116)=-.18, p=.861$.

On support for the leader punishment, the overall model was significant, $F(1,116) 7.23, p<.001, R^{2}=.16$. The main effect of the political organization was significant, $B=.30, t(116)=3.07, p=.003$, as was the main effect of valorization of democracy, $B=.30, t(116)=3.01$, $p=.003$, and both effects were qualified by a significant interaction, $B=-.25, t(116)=-2.52, p=.013$. Simple slope analyses revealed the same pattern of findings that was observed on support for collective punishment: Valorization of democracy increased support for the punishment of the group leader when the offender group was democratic $B=.54, t(116)=3.76, p<.001$, but not when it was nondemocratic, $B=.05, t(116)=.36, p=.717$.

\section{Mediators}

In preparation for the mediation analyses, we separately tested the same model on each of the potential mediators: collective responsibility, violation of expectations, and offender group value.

Collective responsibility. The overall model was non-significant, $F(1,116)$ $1.2, p=.309$, and none of the factors entered in the model were significant ( $p$ s from .117 to .604). For this reason, collective responsibility was no longer considered as a potential mediator in the following mediation analyses ${ }^{1}$.

Expectancy violation. Although the overall model did not reach conventional significance levels, $F(1,116) 1.81, p=.150, R^{2}=.05$, the predicted interaction did, $B=-.23, t(116)=-2.27, p=.025$. Simple slope analyses revealed the same pattern of findings that was observed on punishment judgments: valorization of democracy increased perceptions of violations of expectations when the offender group was democratic, $B=.29, t(116)=2.00, p=.048$, but not when it was nondemocratic, $B=-.16, t(116)=-1.18, p=.239$.

Group value. The overall model was significant, $F(1,116)=6.33$, $p<.001, R^{2}=.147$. The main effects of group political organization, $B=-.21, t(116)=-2.30, p=.023$, and of valorization of democracy, $B=-.27, t(116)=-2.91, p=.004$, were significant. These main effects were qualified by a significant interaction, $B=.28, t(116)=$ $2.99, p=.003$ : When valorization of democracy increased, the perceived group value of the democratic group decreased, $B=-.53$,

\footnotetext{
${ }^{1}$ Even though this question arose for Experiment 6, we have in fact the data to test this alternative explanation in previous experiments as well. Moderated mediation models were thus tested across all other experiments, investigating whether perceived collective responsibility could mediate the effect of the group's political organization on support for collective punishment, specifically at high levels of (manipulated) collective responsibility. Results appears to be supportive of this alternative explanation in Experiment 2 (the indirect effect of perceived collective responsibility at high levels of manipulated collective responsibility was significant, $B=-.27, \mathrm{SE}=.11 ; 95 \% \mathrm{CI}:-.54 ;-.09)$, but not in the other four experiments (the tested indirect effects were not significant. Experiment 3 : $B=-.06, \mathrm{SE}=.13, \mathrm{CI}:-.35 ; .18 ;$ Experiment $4: B=-.02, \mathrm{SE}=.09, \mathrm{CI}:-.21 ; .13 ; \mathrm{Ex}$ periment $5: B=-.09, \mathrm{SE}=.07, \mathrm{Cl}:-.24 ; .03$; Experiment $6: B=.03, \mathrm{SE}=.06, \mathrm{CI}:-.07$ 12). For this reason, we believe it is reasonable to dismiss perceived collective responsibility as an explanation for the effect of a group's political organization on support for collective punishment.
} 
$t(119)=-4.02, p<.001$, but that of the nondemocratic group remained unchanged, $B=.01, t(119)=.06, p=.953$, a pattern of findings that mirrors those evidenced on judgments of (collective and leader) punishments and expectancy violation.

\section{Mediation analyses}

Support for collective punishment. Our hypothesis was that the interaction effect between offender group organization and democracy valorization on support for collective punishment would be mediated both by perceived expectancy violations and by the social value ascribed to the offender group. A serial mediation model tested this prediction.

To test the model of the mediating effect of expectancy violation and group value on the interaction effect of the group organization by valorization of democracy on support for collective punishment and leader punishment, we ran the model 6 of the PROCESS macro (Hayes, 2013) with two serial mediators. The independent variable was the interaction term between group political organization and respondents' valorization of democracy, the dependent variable was support for collective punishment, mediator 1 was expectancy violation and mediator 2 was group value. We also included the main effects of group political organization and valorization of democracy as covariates. If valorization of democracy increases the support for collective punishment of the offending democratic group (when it is highly collectively responsible for an offense) because of expectancy violations which, in turn, decrease the value ascribed to the offending group, then the serial indirect effect of the interaction term on support for collective punishment through expectancy violations and group value should be significant.

As indicated in Fig. 2, the total indirect effect was significant (standardized effect: $B=-.17 ; \mathrm{SE}=.07 ; 90 \% \mathrm{CI}$ : $-.30 ;-.06$ ), as was the serial indirect effect through both mediators, with a standardized point estimate of $B=-.05(S E=.03 ; 90 \% \mathrm{CI}:-.12 ;-.01)$. The simple indirect effect through expectancy violation was not significant $(B=-.003 ; S E=.02 ; 90 \% \mathrm{CI}:-.05 ; .03)^{2}$. This indicates that the effect of expectancy violation on support for collective punishment is entirely mediated by the second serial mediator: group value. Indeed, the simple indirect effect through group value was significant, with a standardized point estimate of $B=-.11(S E=.06 ; 90 \% \mathrm{CI}:-.21 ;-.02)$.

Support for leader punishment. We also tested this model on support for leader punishment (see Fig. 3), arguing that a group leader should be punished according to his group's perceived value, as inferred by its political organization. Interestingly, all indirect effects were significant (total effect: $B=-.15 ; S E=.06 ; 90 \% \mathrm{CI}:-.27 ;-.07$; serial indirect effect: $B=-.04 ; S E=.02 ; 90 \% \mathrm{CI}:-.10 ;-.01$; expectancy violation effect: $B=-.03 ; S E=.03 ; 90 \% \mathrm{CI}:-.11 ;-.0002$; group value effect: $B=$ $-.08 ; S E=.04 ; 90 \% \mathrm{CI}:-.17 ;-.02)$, and the effect of group political organization remained significant $(B=.21, t=2.31, p=.022)$. This indicates that although perceptions of violation of expectations and group value account for some of the variance explaining the support for the punishment of the group leader, its political organization also directly contributes to leader punishment. Overall, this result provides further empirical evidence in support for our understanding of the retributive judgments in terms of value judgments.

\section{Discussion}

The findings of the serial mediation analyses in Experiment 6 showed that, when the offending group was collectively responsible for an offense, democracy valorization increased support for the

\footnotetext{
2 It should be noted that when tested separately, both mediators significantly mediated the effect of the group organization by valorization of democracy interaction on support for collective punishment. The indirect effect of expectancy violation was significant, $B=.06(\mathrm{SE}=.04 ; 90 \% \mathrm{Cl}:-.14 ;-.01)$. The indirect effect of group value was also significant, $B=-.16(\mathrm{SE}=.07 ; 90 \% \mathrm{Cl}:-.29 ;-.06)$.
}

collective punishment of a democratic group, and of its leader. Furthermore, these effects were driven by expectancy violations which, in turn, led to a decrease in the value ascribed to the offending group. Ultimately, such decrease in group value increased the willingness to punish the entire group and its leader for the misconduct of a few of its members. This result indicates that, for people who value democracy, a democratic offender group violates their initial expectancies and thus betrays the social value attached to its political organization. Such disappointment and decrease in the democratic group's value subsequently translates into higher collective punishment. Results on the support for the group leader punishment further support this interpretation: The processes related to the judgments following the offense of democratic group members are rooted in the value ascribed to the group and infuse many different justice judgments in a similar way: the group leader as well as the whole group is punished because the misdeed is perceived as violating prior expectations held towards democratic groups, which in turn decreases the value ascribed to it.

These effects were not found for the nondemocratic group: Valorization of democracy predicted neither collective punishment, expectancy violation, nor group value. This indicates that a nondemocratic group is punished independently of perceptions of expectancy violations or of social value. Given that, prior to any offense, nondemocratic groups are less valued than democratic groups, it is not surprising that expectations towards those groups are lower and hence less violated following the observation of a misdeed.

Perceptions of collective responsibility appeared not to differ as a function of the group political organization, respondents' valorization of democracy, or the interaction between these two factors. Naturally it is likely that, in the absence of any information regarding group members' responsibility, the democratic group members would be held more collectively responsible than nondemocratic groups, given the nature of such groups' organization. In our experiment however, we made it explicit that all group members contributed to the wrongdoing, making it clear that group members of both types of groups were to be held morally responsible. For this reason, in this experiment we expected perceived collective responsibility not to vary as a function of the studied factors, and hence not to account for the differences on support for collective punishment.

\section{General discussion}

What factors trigger the willingness to inflict collective punishment, knowing that innocent individuals would suffer the consequences of a wrongdoing that they did not commit themselves? Following prior studies (Cushman et al., 2012; Falomir-Pichastor et al., 2007), the present research experimentally demonstrated that collective responsibility increases support for collective punishment, and that this effect is moderated by the target group's political organization. The present paper reported six experiments in which we investigated the effects of offender group responsibility and political organization on support for its collective punishment as a response to a misdeed committed by some group members. Although only one, or a few, group members actually committed the wrongdoing, we manipulated the extent to which the rest of the group could be held accountable for this wrongdoing. Experiment 1 showed that higher levels of collective responsibility led to increased levels of support for collective punishment. Experiments 2 to 5 consistently showed that the offender group's political organization moderated this effect: Whereas support for collective punishment of democratic groups constantly increased as their collective responsibility did, this was less the case for nondemocratic groups for which collective responsibility generally did not affect collective punishment. Finally, Experiment 6 provided a better understanding of the processes underlying these effects with a serial mediation analysis through expectancy violations and decreased group value.

Taken together, these studies show how a group can be punished on the sole basis of a moral responsibility attributed to all of its members 


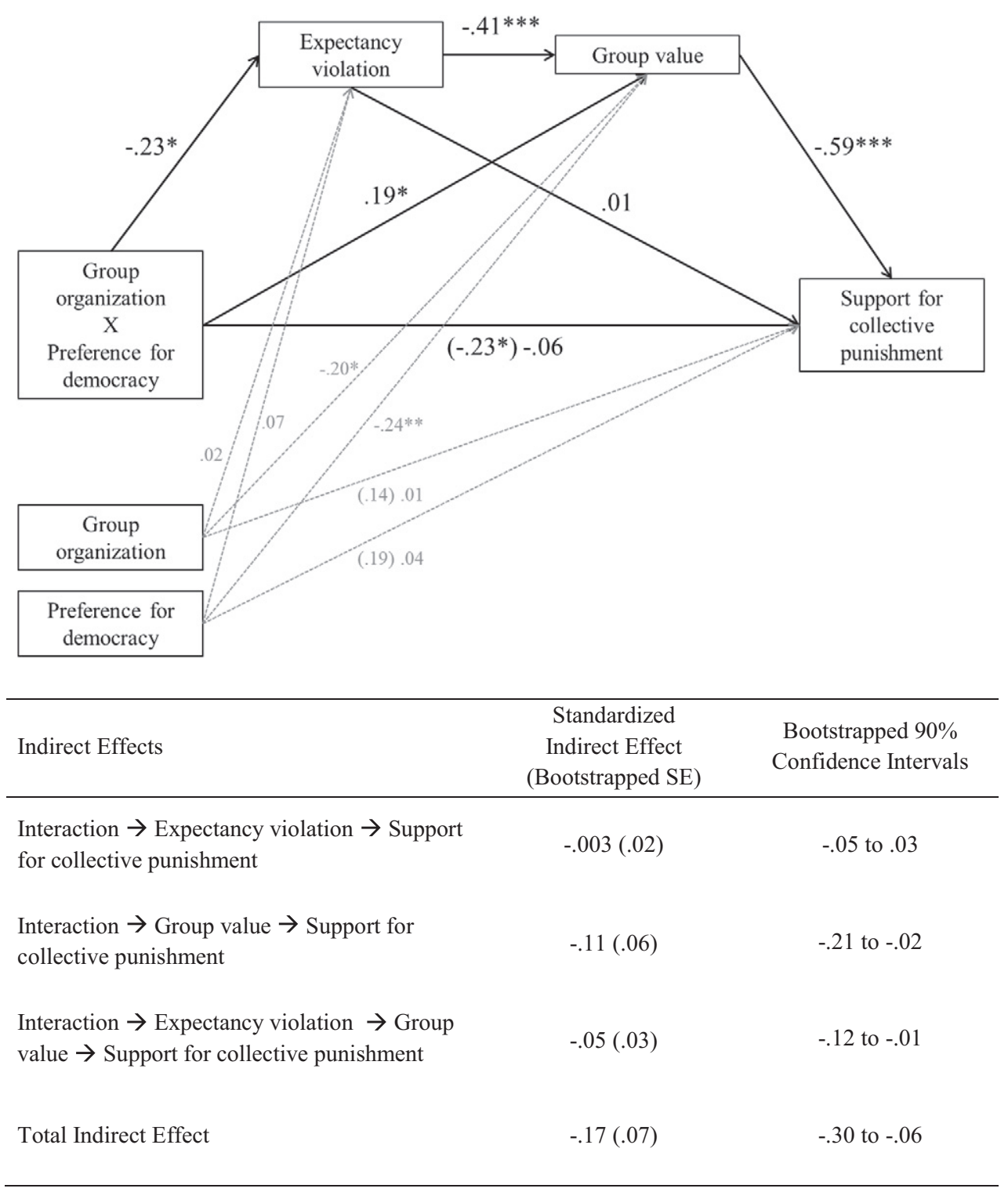

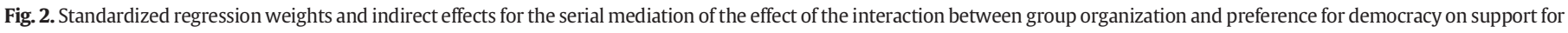
collective punishment through perceptions of expectancy violation and group value, Experiment 6 . $^{* * *}=p<.001,^{* *}=p<.01{ }^{*}=p<.05$.

(that is, even when the group is not causally responsible for an offense), and how the group's political organization moderates the influence of such collective responsibility on support for collective punishment. A democratic offender group, if perceived as collectively responsible for a misdeed, is perceived to be violating the high standards held by people who value democracy. This, in turn, decreases the value ascribed to the democratic group, ultimately leading to an increased willingness to punish such group. These processes are specific to democratic groups, as opposed to nondemocratic ones, and to people who strongly value democracy, as opposed to people who consider democracy less as a value. These findings were evidenced with three scenarios varying the nature of the offense (plagiarism, hooliganism, and vandalism), the kind of collective responsibility (knowing about the misdeed and failing to act, facilitating the emergence of the misdeed, knowing who the culprits are) and the measure of support for collective punishment (going from a single-item measure in Experiments 1 to 4 to a multi-item scale in Experiments 5 and 6).

Contrary to prior research showing that people are motivated to protect democratic groups from punishment (Falomir-Pichastor, Pereira, et al., 2012; Falomir-Pichastor et al., 2007; Pereira et al., 2014), the present research evidenced situations in which people demonstrate more severity in their retributive judgments directed at democratic groups. These findings are consistent with other studies showing that democratic groups are not always protected from punishment, as compared to nondemocratic ones, for example in situations where the victim group is also democratic or unspecified (Falomir-Pichastor et al., 2007; Staerklé, Falomir-Pichastor, Pereira, \& Butera, in preparation). Similarly, wrongful actions perpetrated by democratic groups such as military interventions are no longer legitimized when they are conducted without popular support or against another democratic state (Falomir-Pichastor, Pereira, et al., 2012). In the same vein, research investigating attitudes towards human death toll in the context of the invasion of Iraq evidenced ethnocentric attitudes when the lives of valued group members (i.e., those of American co-nationals and allies) were opposed to lives of devalued outgroup members (i.e., those of Iraqi people), but not when two valued groups competed with each other (Pratto, 2006). In all these situations, the democratic group is penalized for disavowing the democratic values that it is expected to represent: a democratic group should respect its public opinion and know better than to use violence to resolve conflicts (Staerklé et al., 1998), especially 


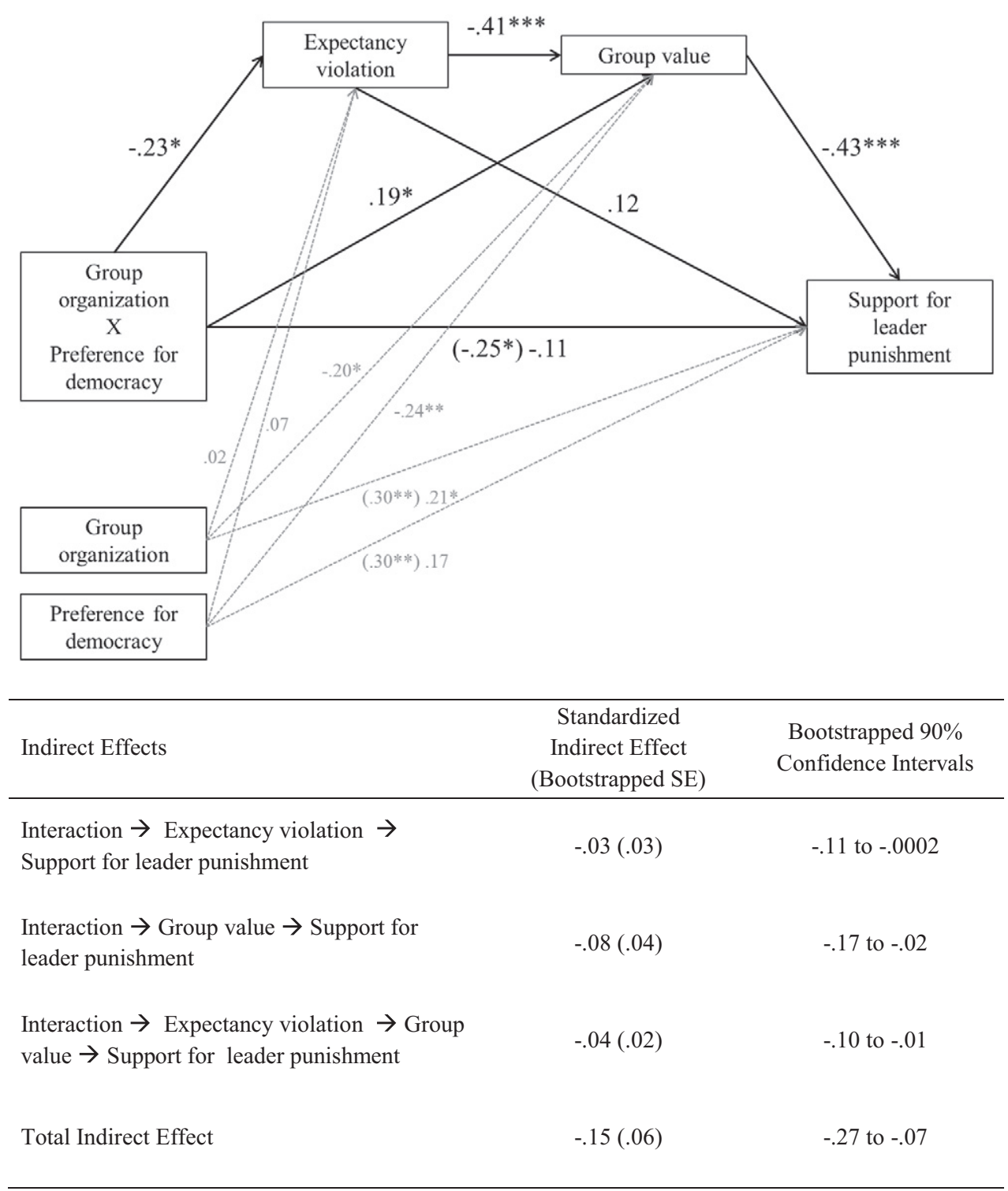

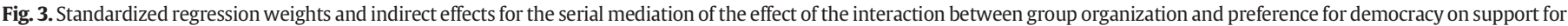
leader punishment through perceptions of expectancy violation and group value. ${ }^{* * *}=p<.001,{ }^{* *}=p<.01,{ }^{*}=p<.05$.

against another democratic group. The present research is the first one to show the crucial role of these higher expectations held towards democratic groups and their consequences on retributive judgments following the violation of such expectations.

Our findings also evidence a situation in which a basic justice principle is not applied: in three of the experiments, collective responsibility did not increase the nondemocratic group's collective punishment. People are willing to punish those groups (more than democratic ones) on the sole basis of their lower group value, but do not take their level of responsibility into account when making retributive judgments. These effects mirror those of other studies showing that offenders' characteristics (e.g., in- or outgroup member, high or low status group member) have a moderating impact on justice judgments such as offense severity, offender intentionality and offender guilt (Gollwitzer \& Keller, 2010; Karelaia \& Keck, 2013; Okimoto \& Wenzel, 2010; van Prooijen, 2006). As for these studies, one possible explanation for the observed effects might be that nondemocratic groups are excluded from the scope of justice within which those basic justice principles determine retributive judgments. Scopes of justice (or moral communities; Cohen, 1991) determine the expectations and behavioral standards when judging others, and different levels of expectations are set for offenders belonging to one scope of justice or another. Moreover, their existence has been evidenced in reference to outgroups as compared to ingroups for distributive justice decisions (Opotow, 1990). Hence, given that collective responsibility only appears to determine collective punishment for democratic groups, it might be that nondemocratic groups are, by default, excluded from the moral community because they violate important democratic values. Future research should investigate whether such exclusion effects are related to value-violating groups or lowstatus groups in general and how exactly they operate.

Overall, these results shed light on political intergroup perceptions and reveal how citizens form judgments about the fairness and legitimacy of international events. Surprisingly enough, this research evidenced conditions under which individuals accept the punishment of valued innocent people, namely when collective responsibility is high and the offender group is democratically organized. Democratic groups therefore pay a price for their higher value: people expect them to behave properly, and when they don't, they face the risk of being 
punished. Hence, the values that we defend appear to drastically impact our perceptions of an offense and our willingness to see the offender group properly punished.

\section{References}

1949 Conventions, additional protocols, their commentaries (1949). Retrieved April 02, 2014, from. http://www.icrc.org/applic/ihl/ihl.nsf/vwTreaties1949.xsp

Alter, A. L., \& Darley, J. M. (2009). When the association between appearance and outcome contaminates social judgment: A bidirectional model linking group homogeneity and collective treatment. Journal of Personality and Social Psychology, 97, 776-795. http://dx.doi.org/10.1037/a0016957.

Biernat, M., Vescio, T. K., \& Billings, L. S. (1999). Black sheep and expectancy violation: Integrating two models of social judgment. European Journal of Social Psychology, 29, 523-542. http://dx.doi.org/10.1002/(SICI)1099-0992(199906)29:4<523::AIDEJSP944>3.0.CO;2-J.

Bin Laden, O. (2002). Full text: Bin Laden's “letter to America.". Retrieved April 01, 2014 from. http://www.theguardian.com/world/2002/nov/24/theobserver

Carlsmith, K. M. (2008). On justifying punishment: The discrepancy between words and actions. Social Justice Research, 21, 119-137. http://dx.doi.org/10.1007/s11211-0080068-X.

Carlsmith, K. M., Darley, J. M., \& Robinson, P. H. (2002). Why do we punish? Deterrence and just deserts as motives for punishment. Journal of Personality and Social Psychology, 83, 284-299. http://dx.doi.org/10.1037//0022-3514.83.2.284.

Cohen, R. L. (1991). Membership, intergroup relations, and justice. In R. Vermunt, \& H. Steensma (Eds.), Social justice in human relations: Vol. 1: Societal and psychological origins of justice, Vol. 1. (pp. 239-258). New York: Plenum Press.

Cushman, F., Durwin, A. J., \& Lively, C. (2012). Revenge without responsibility? Judgments about collective punishment in baseball. Journal of Experimental Social Psychology, 48 , 1106-1110. http://dx.doi.org/10.1016/j.jesp.2012.03.011.

Darley, J. M. (2002). Just punishments: Research on retributional justice. In M. Ross, \& D. T. Miller (Eds.), The justice motive in everyday life (pp. 314-333). Cambridge: Cambridge University Press.

Darley, J. M., \& Pittman, T. S. (2003). The psychology of compensatory and retributive justice. Personality and Social Psychology Review, 7, 324-336. http://dx.doi.org/10.1207/ S15327957PSPR0704_05.

Darley, J. M., \& Schultz, T. R. (1990). Moral rules: Their content and acquisition. Annual Review of Psychology, 41, 525-556 (Retrieved from http://arjournals.annualreviews. org/doi/abs/10.1146/annurev.ps.41.020190.002521).

Denson, T. F., Lickel, B., Curtis, M., Stenstrom, D.M., \& Ames, D. R. (2006). The roles of entitativity and essentiality in judgments of collective responsibility. Group Processes E Intergroup Relations, 9(1), 43-61. http://dx.doi.org/10.1177/ 1368430206059857

Doyle, M. W. (1983). Kant, liberal legacies, and foreign affairs. Philosophy \& Public Affairs, 12, 205-235 (Retrieved from http://www.jstor.org/stable/2265298).

Falomir-Pichastor, J. M., Pereira, A., Staerklé, C., \& Butera, F. (2012). Do all lives have the same value? Support for international military interventions as a function of political system and public opinion of target states. Group Processes \& Intergroup Relations, 15(3), 347-362. http://dx.doi.org/10.1177/1368430211424919.

Falomir-Pichastor, J. M., Staerklé, C., Depuiset, M.A., \& Butera, F. (2005). Democracy justifies the means: Political group structure moderates the perceived legitimacy of intergroup aggression. Personality and Social Psychology Bulletin, 31, 1683-1695. http://dx.doi.org/10.1177/0146167205278260.

Falomir-Pichastor, J. M., Staerklé, C., Depuiset, M. -A., \& Butera, F. (2007). Perceived legitimacy of collective punishment as a function of democratic versus non-democratic group structure. Group Processes E' Intergroup Relations, 10(4), 565-579. http://dx. doi.org/10.1177/1368430207081543.

Falomir-Pichastor, J. M., Staerklé, C., Pereira, A., \& Butera, F. (2012). Democracy as justification for waging war: The role of public support. Social Psychological and Personality Science, 3(3), 324-332. http://dx.doi.org/10.1177/1948550611420172.

Feather, N. T. (1996). Reactions to penalties for an offense in relation to authoritarianism, values, perceived responsibility, perceived seriousness, and deservingness. Journal of Personality and Social Psychology, 71, 571-587 (Retrieved from http://www.ncbi.nlm. nih.gov/pubmed/8831162)

Feather, N. T. (1999). Judgments of deservingness: Studies in the psychology of justice and achievement. Personality and Social Psychology Review, 3, 86-107. http://dx.doi. org/10.1207/s15327957pspr0302_1.

Feinberg, J. (1968). Collective responsibility. The Journal of Philosophy, 65, 674-688 (Retrieved from http://www.jstor.org/stable/2024543).

Gaertner, L., \& Iuzzini, J. (2005). Rejection and entitativity: A synergistic model of mass violence. In K. D. Williams, J. P. Forgas, \& W. von Hippel (Eds.), The social outcast: Ostracism, social exclusion, rejection, and bullying (pp. 307-320). New York: Psychology Press.

Gaertner, L., Iuzzini, J., \& O'Mara, E. M. (2008). When rejection by one fosters aggression against many: Multiple-victim aggression as a consequence of social rejection and perceived groupness. Journal of Experimental Social Psychology, 44, 958-970. http:// dx.doi.org/10.1016/j.jesp.2008.02.004.

Gollwitzer, M., \& Keller, L. (2010). What you did only matters if you are one of us: Offenders' group membership moderates the effect of criminal history on punishment severity. Social Psychology, 41(1), 20-26 (retrieved from http://dx.doi.org/10. 1027/1864-9335/a000004)

Hart, H. L. A. (1968). Punishment and responsibility. New York: Oxford University.

Hayes, A. F. (2013). Introduction to mediation, moderation, and conditional process analysis: A regression based approach. New York, NY: Guilford Press.
Healy, A. F., Hoffman, J. M., Beer, F. A., \& Bourne, L. E., Jr. (2002). Terrorists and democrats: Individual reactions to international attacks. Political Psychology, 23, 439-467. http:// dx.doi.org/10.1111/0162-895X.00293.

Heckathorn, D.D. (1988). Collective sanctions and the creation of prisoner's dilemma norms. American Journal of Sociology, 94, 535-562 (Retrieved from http://www. jstor.org/stable/2780253)

Heckathorn, D.D. (1990). Collective sanctions and compliance norms: A formal theory of group-mediated social control. American Sociological Review, 55, 366-384 (Retrieved from http://www.jstor.org/stable/2095762).

Hedges, L. V., \& Olkin, I. (1985). Statistical methods for meta-analysis. Orlando, FL: Academic Press.

Iyer, A., Jetten, J., \& Haslam, S. A. (2012). Sugaring o'er the devil: Moral superiority and group identification help individuals downplay the implications of ingroup rulebreaking. European Journal of Social Psychology, 42, 141-149. http://dx.doi.org/10. 1002/ejsp.864.

Jussim, L., Coleman, L. M., \& Lerch, L. (1987). The nature of stereotypes: A comparison and integration of three theories. Journal of Personality and Social Psychology, 52(3), 536-546. http://dx.doi.org/10.1037/0022-3514.52.3.536.

Kant, I. (1952). The science of right. In R. Hutchins (Ed.), Great books of the Western world: Vol. 42. Kant (pp. 397-446). Edinburg: T. \& T. Clark (original work published in 1790).

Karelaia, N., \& Keck, S. (2013). When deviant leaders are punished more than non-leaders: The role of deviance severity. Journal of Experimental Social Psychology, 49, 783-796. http://dx.doi.org/10.1016/j.jesp.2013.04.003.

Kerr, N. L., Hymes, R. W., Anderson, A. B., \& Weathers, J. E. (1995). Defendant-juror similarity and mock juror judgments. Law and Human Behavior, 19, 545-567. http://dx.doi.org/10.1007/BF01499374.

Lai, J., Fidler, F., \& Cumming, G. (2012). Subjective p intervals. Methodology: European Journal of Research Methods for the Behavioral and Social Sciences, 8(2), 51-62. http://dx.doi.org/10.1027/1614-2241/a000037.

Lickel, B., Hamilton, D. L., Wieczorkowska, G., Lewis, A., Sherman, S. J., \& Uhles, A. N. (2000). Varieties of groups and the perception of group entitativity. Journal of Personality and Social Psychology, 78, 223-246. http://dx.doi.org/10.1037//00223514.78.2.223.

Lickel, B., Miller, N., Stenstrom, D.M., Denson, T. F., \& Schmader, T. (2006). Vicarious retribution: The role of collective blame in intergroup aggression. Personality and Social Psychology Review, 10, 372-390. http://dx.doi.org/10.1207/s15327957pspr1004_6.

Lickel, B., Schmader, T., \& Hamilton, D. L. (2003). A case of collective responsibility: Who else was to blame for the Columbine high school shootings? Personality and Social Psychology Bulletin, 29, 194-204. http://dx.doi.org/10.1177/ 0146167202239045.

Lieberman, D., \& Linke, L. (2007). The effect of social category on third party punishment Evolutionary Psychology, 5, 289-305 (Retrieved from http://www.epjournal.net/wpcontent/uploads/EP05289305.pdf).

Lipsey, M. W., \& Wilson, D. B. (2001). Practical meta-analysis. Thousand Oaks, CA: Sage Publications.

Marques, J. M., Abrams, D., Paez, D., \& Martinez-Taboada, C. (1998). The role of categorization and in-group norms in judgments of groups and their members. Journal of Personality and Social Psychology, 75, 976-988. http://dx.doi.org/10.1037/0022-3514.75.4.976.

Marques, J. M., Abrams, D., \& Serôdio, R. G. (2001). Being better by being right: Subjective group dynamics and derogation of in-group deviants when generic norms are undermined. Journal of Personality and Social Psychology, 81, 436-447. http://dx.doi. org/10.1037/0022-3514.81.3.436.

Marques, J. M., \& Paez, D. (1994). The "Black Sheep Effect": Social categorization, rejection of ingroup deviates, and perception of group variability. European Review of Social Psychology, 5, 37-68. http://dx.doi.org/10.1080/14792779543000011.

May, L. (1987). The morality of groups: Collective responsibility, group-based harm, and corporate rights. Notre Dame, IN: University of Notre Dame Press (Retrieved from http://www.getcited.org/pub/102638469).

Milgram, S. (1974). Obedience to authority: An experimental view. New York: Harper \& Row (Retrieved from http://onlinelibrary.wiley.com/mrw_content/wbepp/articles/ wbepp182/wbepp182.pdf)

Miller, D. T. (2001). Disrespect and the experience of injustice. Annual Review of Psychology, 52, 527-553. http://dx.doi.org/10.1146/annurev.psych.52.1.527.

Newheiser, A. -K., Sawaoka, T., \& Dovidio, J. F. (2012). Why do we punish groups? High entitativity promotes moral suspicion. Journal of Experimental Social Psychology, 48, 931-936. http://dx.doi.org/10.1016/j.jesp.2012.02.013.

Okimoto, T. G., \& Wenzel, M. (2010). The other side of perspective taking: Transgression ambiguity and victims' revenge against their offender. Social Psychological and Personality Science, 2, 373-378. http://dx.doi.org/10.1177/1948550610393032.

Opotow, S. (1990). Moral exclusion and injustice: An introduction. Journal of Social Issues, 46, 1-20. http://dx.doi.org/10.1111/j.1540-4560.1990.tb00268.x.

Pereira, A., Falomir-Pichastor, J. M., Berent, J. A., Staerklé, C., \& Butera, F. (2014). In the name of democracy: The value of democracy explains leniency towards wrongdoings as a function of group political organization. Manuscript in Revision.

Piaget, J. (1932). The moral judgment of the child. London: Kegan Paul.

Pratto, F. (2006). Weighing the prospects of war. Group Processes E Intergroup Relations, 9, 219-233. http://dx.doi.org/10.1177/1368430206062078.

Schultz, T. R., \& Schleifer, M. (1983). Towards a refinement of attribution concepts. In J Jaspars, F. D. Fincham, \& M. Hewstone (Eds.), San Diego, CA: Academic Press.

Staerklé, C., Clémence, A., \& Doise, W. (1998). Representation of human rights across different national contexts: The role of democratic and non-democratic populations and governments. European Journal of Social Psychology, 28, 207-226. http://dx.doi. org/10.1002/(SICI)1099-0992(199803/04)28:2<207::AID-EJSP865>3.0.CO;2-5.

Staerklé, C., Falomir-Pichastor, J. M., Pereira, A., \& Butera, F. (2014n). Democratic value protection: Egalitarians stop being nice when they are in conflict with hierarchical groups. (in preparation). 
Stenstrom, D.M., Lickel, B., Denson, T. F., \& Miller, N. (2008). The roles of ingroup identification and outgroup entitativity in intergroup retribution. Personality and Socia Psychology Bulletin, 34, 1570-1582. http://dx.doi.org/10.1177/0146167208322999.

Tajfel, H., \& Turner, J. C. (1986). The social identity theory of intergroup behavior. In S. Worchel, \& W. G. Austin (Eds.), Psychology of intergroup relations (pp. 7-24). Chicago, IL: Nelson Hall.

van Prooijen, J. -W. (2006). Retributive reactions to suspected offenders: The importance of social categorizations and guilt probability. Personality and Social Psychology Bulletin, 32, 715-726. http://dx.doi.org/10.1177/0146167205284964.

van Prooijen, J. -W. (2010). Offenders' social categorization: Ingroup bias or black sheep effect? In M. E. Oswald, S. Bieneck, \& J. Hupfeld-Heinemann (Eds.), Social psychology of punishment of crime (pp. 211-229). Chichester: Wiley-Blackwell.

Vidmar, N., \& Miller, D. T. (1980). Socialpsychological processes underlying attitudes toward legal punishment. Law \& Society Review, 14, 565-602 (Retrieved from http://heinonlinebackup.com/hol-cgi-bin/get_pdf.cgi?handle=hein.journals/ lwsocrw14\&amp;section=28)

White, N. D. (1994). Collective danctions: An alternative to military coercion? International Relations, 12, 75-91. http://dx.doi.org/10.1177/004711789401200305.

Whitmeyer, J. M. (2002). The compliance you need for a cost you can afford: How to use individual and collective sanctions? Social Science Research, 31, 630-652. http://dx. doi.org/10.1016/S0049-089X(02)00017-0.

Yzerbyt, V. Judd, C. M., \& Corneille, O (2004). Perceived variability, entitativity, and essentialism: Introduction and overview. In V. Yzerbyt, C. M. Judd, \& O. Corneille (Eds.), The psychology of group perception: Perceived variability, entitativity, and essentialism (pp. 1-22). New York: Psychology Press.

Zimmermann, A., Abrams, D., Doosje, B., \& Manstead, A. S. R. (2011). Causal and moral responsibility: Antecedents and consequences of group-based guilt. European Journal of Social Psaychology, 41, 825-839. http://dx.doi.org/10.1002/ejsp.826. 